\title{
DOSTĘPNOŚĆ EDUKACJI PODSTAWOWEJ NA OBSZARACH WIEJSKICH WOJEWÓDZTWA MAŁOPOLSKIEGO - STUDIUM PRZYPADKU POWIATU MIECHOWSKIEGO
}

\section{ACCESSIBILITY TO PRIMARY EDUCATION IN RURAL AREAS OF THE MAŁOPOLSKIE VOIVODSHIP - CASE STUDY OF MIECHÓW DISTRICT}

\author{
Agnieszka GIL • Marcin SEMCZUK \\ Uniwersytet Pedagogiczny im. KEN w Krakowie \\ Instytut Geografii \\ ul. Podchorążych 2, 30-084 Kraków \\ agnieszka.gil@wp.pl•semczuk@up.krakow.pl
}

Zarys treści: W wyniku niekorzystnych tendencji demograficznych w ostatnich latach w Polsce obserwuje się znaczący ubytek liczby uczniów w szkołach podstawowych. Konsekwencją tych zmian jest likwidacja małych szkół zlokalizowanych głównie na obszarach wiejskich. Powoduje to wydłużenie czasu dojazdu dzieci do szkół. Artykuł przedstawia zmiany w sieci szkół województwa małopolskiego oraz zjawiska ludnościowe, które w głównej mierze za nie odpowiadają. Skupiono się na najbardziej depopulacyjnym regionie województwa, powiecie miechowskim, położonym w jego północno-wschodniej części. Dla powiatu miechowskiego przedstawiono zmiany ludności w latach 1950-2012, które doprowadziły do trudnej sytuacji demograficznej regionu. Następnie porównano poziom dostępności czasowej do szkół podstawowych powiatu miechowskiego w roku 2008 oraz 2014. Starano się również ocenić organizację zajęć pozalekcyjnych, jako istotnego czynnika wyrównywania szans kształcenia dzieci i młodzieży.

Słowa kluczowe: dostępność szkolnictwa, obszary wiejskie, Małopolska, szkoła podstawowa, edukacja.

\section{Wprowadzenie}

Na współczesną sieć szkół podstawowych oddziałuje wiele uwarunkowań, najsilniej procesy demograficzne ze zmienną przestrzennie liczbą urodzeń i postępującą koncentracją osadnictwa. Znaczny spadek liczby urodzeń poważnie ogranicza tworzenie coraz lepszych warunków kształcenia dzieci, które są głównym celem realizowanej obecnie polityki oświatowej. Generalnie województwo małopolskie cechuje się stałym wzrostem zaludnienia związanym z dodatnim wskaźnikiem przyrostu naturalnego, jak i korzystnym saldem migracji, jednak na terenach rolniczych procesy ludnościowe cechuje ujemny przyrost naturalny i niekorzystny bilans migracyjny. 
Przesłankami do podjęcia badań dotyczących dostępności edukacji podstawowej był proces likwidowania małych szkół na obszarach wiejskich w Polsce. Szczególnie widoczne było to na obszarach, gdzie funkcja rolnicza odgrywa dominującą rolę (Uliszak 2013). W latach 2008-2014 w województwie małopolskim największą liczbę szkół (13) zlikwidowano w powiecie miechowskim. Z tego powodu obszar ten wybrano do badań szczegółowych. Starano się pokazać, jak w tym silnie depopulacyjnym regionie Małopolski demograficzne uwarunkowania wpływają na zmiany sieci szkół, a także, jak trendy ludnościowe ograniczają dostępność dzieci i młodzieży do różnych form kształcenia pozalekcyjnego. Celem artykułu jest przedstawienie najważniejszych zjawisk ludnościowych w województwie małopolskim, ponadto zaprezentowanie rozmieszczenia i dostępności szkół podstawowych w powiecie miechowskim, a także ocena organizacji zajęć pozalekcyjnych, jako istotnego czynnika wyrównywania szans kształcenia dzieci i młodzieży.

W artykule wykorzystano dane dotyczące zmian liczby ludności dla województwa małopolskiego w latach 2002-2013, dla powiatu miechowskiego w latach 1950-2012 oraz dane dotyczące liczby szkół, wydatków na dowożenie dzieci, a także liczby uczniów z lat 2000-2013. Ponadto do porównania dostępności czasowej do szkół podstawowych wykorzystano sieć dróg aktualną dla roku 2008 i 2014.

Kluczowym pojęciem dla realizacji przedmiotu i celu pracy jest pojęcie dostępności. Według M. Moseleya (1979) dostępność można rozpatrywać z perspektywy przestrzennej, ekonomicznej oraz społecznej, w zależności od określenia łatwości skorzystania z określonych funkcji. Dostępność społeczna, jako przedmiot badań socjologów, określa w jakim stopniu posiadane środki, status czy położenie społeczne umożliwiają osiągnięcie jakiegoś miejsca lub dobra. Natomiast dostępność ekonomiczna zwraca największą uwagę na monetarne koszty pokonania jednostki odległości. Z perspektywy niniejszej pracy najistotniejsze znaczenie ma pojęcie dostępności przestrzennej, którą za R. Guzikiem (2003) zdefiniowano jako łatwość osiągnięcia miejsca lub funkcji z innego miejsca/miejsc wyrażoną dystansem do pokonania, kosztem transportu lub czasem podróży. Jednocześnie uznano, że najistotniejszym z punktu widzenia dostępności do szkolnictwa podstawowego jest czas podróży, dlatego też w przeprowadzonych badaniach miernikiem dostępności szkół podstawowych był czas dojazdu.

Dotychczasowy dorobek podejmujący zagadnienia dostępności do szkolnictwa w polskiej literaturze jest stosunkowo duży, jednak w większości przypadków dotyczy szkolnictwa ponadpodstawowego i na ogół obszarów miejskich. Dotychczasowe badania koncentrowały się na: zmianach w sieci szkół na wsi (Ozga 1960, 1974; Piwowarski 1992, 200; Domalewski 2010; Gil i Semczuk 2014), rejonizacji kształcenia i związanymi z tym problemami (Bajerski 2011, 2012, 2014; Piwowarski 1992), jakości kształcenia na wsi (Domalewski 2002, Flaga i Wesołowska 2002; Pilch 2002), preferencjach uczniów w wyborze szkoły i zadowolenia ze szkoły (Majkut 2010; Dolata 2008; Kaczan i in. 2012), barierach w edukacji na obszarach wiejskich (Rydz 2002; Wilkin 2003). Natomiast zagadnienie przestrzennej dostępności do szkół zostało podjęte m.in. w pracach A. Szyszko-Bohusza (1974), Z. Kwiecińskiego (1975), Z. Taylora (1999), R. Piwowarskiego (1992), R. Guzika (2003, 2013), K. Czapiewskiego i K. Janca (2011, 2012), M. Dej i R. Guzika (2011). 


\section{Kształtowanie się sieci szkół podstawowych w województwie małopolskim}

Organizowanie sieci szkół w skali lokalnej jest uzależnione od samorządów gminnych i jest szczegółowo opisane w Ustawie o systemie oświaty z dnia 7 września 1991 r. Ustalone są w niej m.in. maksymalne odległości lokalizacji szkoły od miejsca zamieszkania ucznia. W przypadku szkół podstawowych - dla klas I-IV odległość, od której przysługuje dziecku bezpłatny dowóz do szkoły (lub zwrot kosztów przejazdu środkami komunikacji publicznej) to $3 \mathrm{~km}$, natomiast dla klas $\mathrm{V}-\mathrm{VI}-4 \mathrm{~km}$. Według obowiązujących przepisów prawnych dostępność do szkolnictwa rozumiana jest przede wszystkim w ujęciu geograficznym. Przy czym długość drogi powinna być mierzona nie w linii prostej, ale z uwzględnieniem lokalnych uwarunkowań, w tym rzeźby terenu i połączeń drogowych.

W województwie małopolskim w 2012 r. znajdowało się łącznie 1399 szkół podstawowych (bez specjalnych) i w stosunku do 2000 r. nastąpił ich spadek o 12,3 punków procentowych. W jeszcze większej skali zmniejszyła się tutaj populacja uczniów szkół podstawowych. W okresie 2000-2012 spadła ona bowiem o ponad 80 tys. (z ponad 280 do niecałych 200 tysięcy, tj. o blisko 30\%) (ryc. 1).

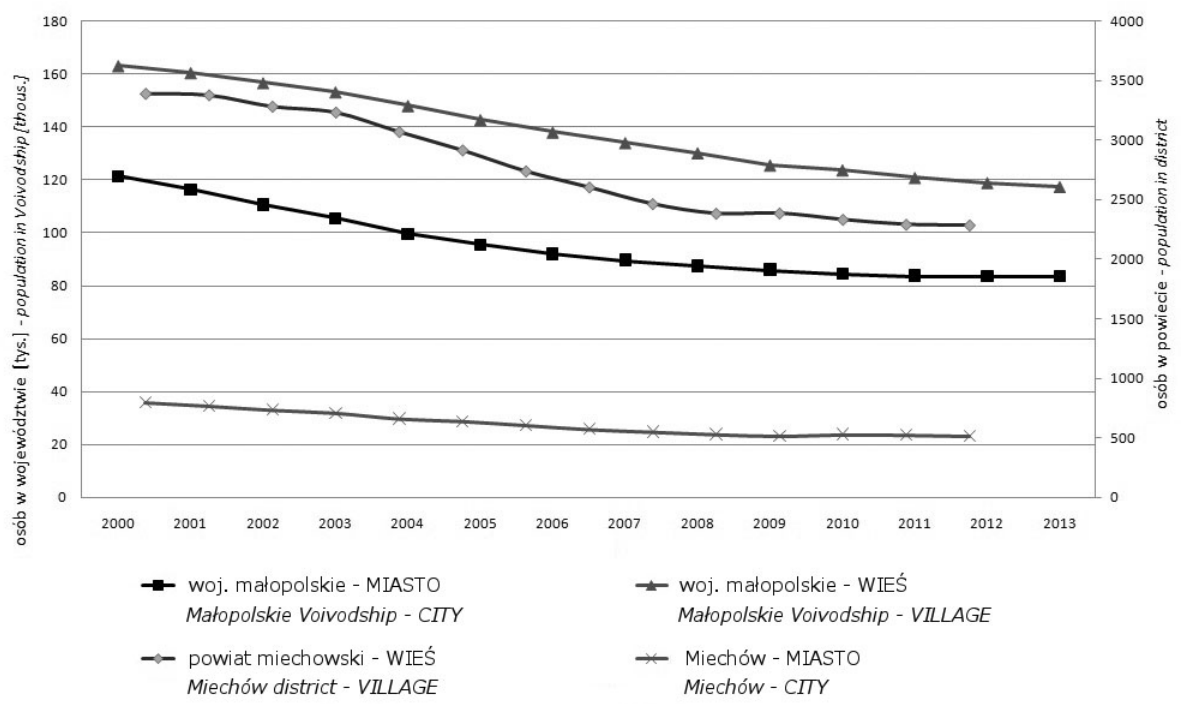

Ryc. 1. Liczba osób w wieku 7-12 w latach 2000-2013 w województwie małopolskim oraz w powiecie miechowskim

Źródło: opracowanie własne na podstawie BDL GUS.

Population aged 7-12 in the years 2000-2013 in the Małopolskie Voivodship and Miechów district Source: own compilation based on Local Data Bank.

Niekorzystne tendencje demograficzne występują zarówno miastach, jak i na obszarach wiejskich, ale ich skutki w postaci zamykania szkół szczególnie widoczne były na obszarach wiejskich. Redukcja liczby szkół byłaby niewątpliwie znacznie wyższa, gdyby nie aktywność społeczności lokalnych, które korzystały z możliwości ich przejęcia poprzez zakładanie stowarzyszeń i organizacji społecznych. Tak więc wraz ze spadkiem liczby szkół samorządowych nastąpił znaczny wzrost liczby szkół prowadzonych przez stowarzyszenia oraz inne jednostki niebędące jednostkami samorządu terytorialnego. Szczególnie 
widoczne jest to w powiatach tarnowskim i krakowskim, gdzie w analizowanych latach powstało tam odpowiednio 30 i 12 szkół prowadzonych przez takie organizacje. Zamykanie placówek nie jest wprost proporcjonalne do zmniejszającej się liczby uczniów, o czym świadczy zwiększenie się liczby szkół podstawowych na 10 tys. osób w wieku 7-12 lat w większości powiatów województwa małopolskiego. Wyjątkiem jest powiat miechowski, w którym ta liczba zmalała. Jest to zarazem jedyny powiat, w którym zmniejszyła się istotnie dostępność do szkolnictwa podstawowego (tab. 1).

Tabela 1. Zmiany zróżnicowania regionalnego szkolnictwa podstawowego w województwie małopolskim w latach 2000-2013

\begin{tabular}{|c|c|c|c|c|c|c|c|c|}
\hline \multirow[t]{2}{*}{$\begin{array}{l}\text { Jednostka terytorial- } \\
\text { na (powiaty) }\end{array}$} & \multicolumn{2}{|c|}{$\begin{array}{l}\text { Liczba szkół pro- } \\
\text { wadzonych przez } \\
\text { jednostki samo- } \\
\text { rządu gminnego }\end{array}$} & \multicolumn{2}{|c|}{$\begin{array}{l}\text { Szkoły prowa- } \\
\text { dzone przez inne } \\
\text { organizacje }\end{array}$} & \multicolumn{2}{|c|}{$\begin{array}{l}\text { Ludność w wieku } \\
\text { poprodukcyjnym } \\
\text { na } 100 \text { osób } \\
\text { w wieku przed- } \\
\text { produkcyjnym }\end{array}$} & \multicolumn{2}{|c|}{$\begin{array}{l}\text { Liczba szkół pod- } \\
\text { stawowych na } 10 \\
\text { tys. mieszkańców } \\
\text { w wieku 7-12 lat }\end{array}$} \\
\hline & 2000 & 2013 & 2000 & 2013 & 2002 & 2013 & 2000 & 2013 \\
\hline Krakowski & 145 & 114 & 0 & 14 & 64,5 & 83,4 & 69 & 76 \\
\hline Nowosądecki & 142 & 121 & 2 & 12 & 42,3 & 57,7 & 68 & 82 \\
\hline Tarnowski & 139 & 96 & 0 & 30 & 52,3 & 75,9 & 73 & 97 \\
\hline Miasto Kraków & 137 & 99 & 22 & 37 & 94,4 & 135,2 & 34 & 39 \\
\hline Nowotarski & 119 & 101 & 0 & 6 & 46,9 & 72,5 & 64 & 83 \\
\hline Limanowski & 93 & 81 & 1 & 3 & 44,4 & 58,4 & 74 & 84 \\
\hline Wadowicki & 83 & 67 & 0 & 4 & 55,8 & 81,4 & 56 & 70 \\
\hline Gorlicki & 68 & 57 & 1 & 4 & 56,4 & 83,6 & 65 & 88 \\
\hline Bocheński & 63 & 53 & 0 & 3 & 51,8 & 74,3 & 63 & 81 \\
\hline Myślenicki & 63 & 54 & 0 & 4 & 46,9 & 65,6 & 53 & 68 \\
\hline Brzeski & 60 & 47 & 0 & 2 & 52,9 & 77,6 & 66 & 81 \\
\hline Olkuski & 56 & 42 & 0 & 8 & 70,5 & 114,6 & 56 & 84 \\
\hline Wielicki & 56 & 48 & 1 & 2 & 58,7 & 73,6 & 62 & 64 \\
\hline Oświęcimski & 53 & 45 & 1 & 3 & 67,5 & 106,8 & 41 & 56 \\
\hline Suski & 48 & 40 & 0 & 3 & 58 & 79,9 & 61 & 77 \\
\hline Chrzanowski & 45 & 36 & 1 & 4 & 74,1 & 119,7 & 45 & 61 \\
\hline Miechowski & 43 & 21 & 0 & 2 & 88,4 & 122,8 & 103 & 82 \\
\hline Dąbrowski & 41 & 26 & 0 & 4 & 58,1 & 87,9 & 70 & 85 \\
\hline Tatrzański & 35 & 33 & 2 & 2 & 61,6 & 90,6 & 60 & 83 \\
\hline Proszowicki & 34 & 22 & 1 & 3 & 71,6 & 102,5 & 90 & 98 \\
\hline Miasto Tarnów & 20 & 14 & 3 & 6 & 68,7 & 128,6 & 24 & 35 \\
\hline Miasto Nowy Sącz & 16 & 14 & 1 & 4 & 52,8 & 94,4 & 22 & 36 \\
\hline $\begin{array}{l}\text { Ogółem województwo } \\
\text { małopolskie }\end{array}$ & 1559 & 1231 & 36 & 160 & 63,2 & 92,3 & 56 & 69 \\
\hline
\end{tabular}

Źródło: opracowanie własne na podstawie BDL GUS. 


\section{Ruch naturalny i migracyjny na obszarach wiejskich województwa małopolskiego (typologia Webba)}

W celu przedstawienia zmian ludnościowych woj. małopolskiego, które w istotny sposób wpływają na sytuację szkolnictwa, dokonano analizy obszarów wiejskich ze względu na ruch naturalny oraz saldo migracji. Na podstawie tych zmiennych wyznaczono typy gmin w dwóch przekrojach czasowych, dzięki czemu można wskazać tendencje, jakie miały miejsce w dłuższym okresie (średnie z lat 2002-2004 oraz 2011-2013) w badanych jednostkach przestrzennych.

Związek między ruchem naturalnym oraz migracjami określono poprzez procedurę Webba, która jako jedna z bardziej znanych metod przedstawia zależność między przyrostem lub ubytkiem naturalnym oraz dodatnim lub ujemnym saldem migracji. Daje ona możliwość wyróżnienia 8 kombinacji (typów). Cztery typy o przyroście rzeczywistym dodatnim (A, B, C, D) różnią się tym, że przyrost naturalny przewyższa straty migracyjne $(A)$, albo przeważa nad przyrostem migracyjnym (B). Typ C określany jest w jednostkach, gdzie przyrost migracyjny przewyższa przyrost naturalny, a typ D w jednostkach, gdzie przyrost migracyjny jest większy od ubytku naturalnego. Pozostałe cztery typy obejmują jednostki z ubytkiem absolutnym, który wynika z przewagi ubytku naturalnego nad imigracją (E) lub emigracją (F), albo przewagi emigracji nad ubytkiem (G) lub przyrostem naturalnym (H) (Jędrzejczyk 2001).

Z przeprowadzonej typologii wynika, że w latach 2002-2004 na małopolskiej wsi przewagę miały gminy, w których dominował przyrost rzeczywisty ludności (139 gmin), natomiast tylko w 27 gminach zaobserwowano ubytek rzeczywisty (ryc. 2). Rozkład poszczególnych typów przybrał układ pasmowy. Przyrost rzeczywisty spowodowany przewagą przyrostu naturalnego nad saldem migracji (typ B w klasyfikacji Webba) charakterystyczny jest dla południowej części województwa i obejmuje największą liczbę jednostek (50 gmin). Jednocześnie w tej części Małopolski wyraźnie zaznaczają się dwa obszary (zachodnia część Beskidu Wyspowego i południowa Pogórza Ciężkowickiego), w których dodatni przyrost naturalny kompensuje ujemne saldo migracji (typ A). Pas rozciągający się w centralnej części województwa to głównie typ C, którego przewaga widoczna jest na południe od Krakowa, a przyrost ludności w głównej mierze uzależniony był od salda migracji. Natomiast na obszarach wiejskich zlokalizowanych na północ od Krakowa dominował typ D, w którym występował już ujemny przyrost naturalny, jednak kompensowany dodatnim saldem migracji. Ubytek liczby ludności zaznaczył się w północnej części województwa (21 z 27 gmin), gdzie dominującą jest funkcja rolnicza. Jedynym powiatem w Małopolsce, w którym wystąpił ubytek ludności na całym jego obszarze był powiat miechowski.

W latach 2011-2013 w dalszym ciągu na większości obszarów wiejskich Małopolski dominował przyrost rzeczywisty ludności i był najczęściej wynikiem dominacji przyrostu naturalnego nad saldem migracji (typ B, 53 gminy) i odwrotnie (typ C, 40 gmin). Liczba gmin wiejskich charakteryzująca się przyrostem ludności zmniejszyła się w stosunku do wcześniejszego okresu z 139 do 135, głównie za sprawą zmniejszenia o 12 gmin przypisanych typowi $D$, natomiast łącznie jednostki przypisane typom B i C zwiększyły swoją liczbę z 87 do 93. Porównując omawiane przekroje czasowe, można wyróżnić typy obszarów wiejskich, w których nastąpił progres (zmiana z ubytku na przyrost rzeczywisty), stały progresywny (stały przyrost), stały regresywny (stały ubytek) i typ regresywny (z przyrostu 

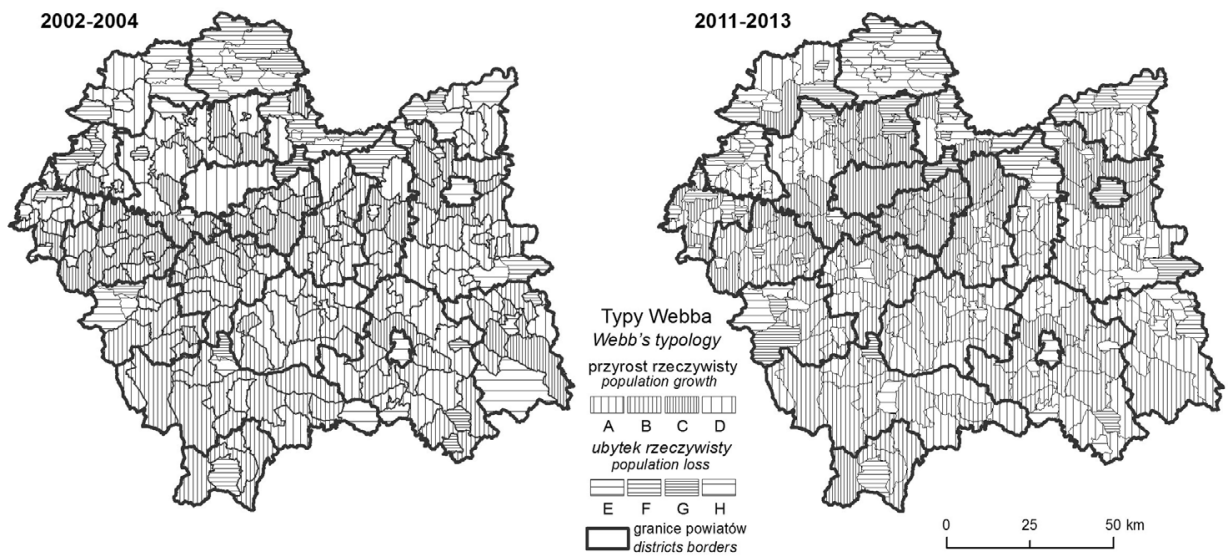

Ryc. 2. Typologia demograficzna województwa małopolskiego według gmin w latach 2002-2013 (według Webba) Źródło: opracowanie własne na podstawie BDL GUS.

Demographic typology of the Małopolskie Voivodship by communes in the years 2002-2013 (according to Webb) Source: own compilation based on Local Data Bank.

na ubytek rzeczywisty). W 82\% gminach wiejskich Małopolski obserwowano w omawianych latach wzrost zaludnienia (typ progresywny i stały progresywny), natomiast na obszarach wiejskich z rolniczej północnej części województwa oraz tych w części południowej, ale położonych peryferyjnie (zachodnie gminy powiatu suskiego i gminy graniczące z woj. podkarpackim w południowo-wschodniej części województwa) nastąpił spadek liczby ludności. Pozytywny trend w postaci typu progresywnego odnotowano w 7 gminach, w tym 5 z rolniczej północy, były to gminy: Szczucin, Olesno, Nowe Brzesko, Radziemice oraz obszar wiejski miasta Wolbrom. Jednak większość tego obszaru cechuje się stałym odpływem ludności, a gminy wiejskie, tj. Pałecznica i Mędrzechów, które w latach 2002-2004 pozytywnie odróżniały się przyrostem ludności, obecnie są terenami wiejskimi o szybkim ubytku ludności, zarówno poprzez ubytek naturalny, jak i ujemne saldo migracji. Utrwalające się niekorzystne zmiany demograficzne potwierdza rosnący udział osób w wieku poprodukcyjnym w każdym z powiatów województwa małopolskiego. Wskaźnik obciążenia ludności w wieku poprodukcyjnym na 100 osób w wieku przedprodukcyjnym dla roku 2013 aż w sześciu powiatach (miechowskim, chrzanowskim, olkuskim, oświęcimskim, proszowickim oraz w miastach Kraków, Nowy Sącz, Tarnów) przekroczył 100. Wynika z tego, że już teraz w tych powiatach jest spora nadwyżka osób w wieku poprodukcyjnym nad osobami w wieku przedprodukcyjnym (tab. 1). W ten niekorzystny trend w największym stopniu wpisuje się powiat miechowski, w którym wszystkie gminy mają charakter stale regresywny zarówno wiejskie, jak i jedyne miasto na obszarze powiatu - Miechów.

\section{Obraz demograficzny powiatu miechowskiego}

Powiat miechowski, obejmuje zasięgiem 7 gmin, w tym 6 wiejskich oraz gminę miejsko-wiejską Miechów. Obecna sytuacja demograficzna regionu jest wynikiem zachodzących od lat 50. ubiegłego wieku niekorzystnych zmian. Świadczy o tym spadek liczby ludności w latach 1950-2012 (z 60456 do 49906 mieszkańców), który przekroczył 17\%. Najwięk- 
szy spadek liczby ludności odnotowano w latach 90. Wyniósł on prawie 9\%. Jedynie w 13 miejscowościach tego powiatu (9,4\% ogółu) w analizowanym okresie przybyło ludności. Dotyczyło to jednak miejscowości zlokalizowanych w pobliżu Miechowa, przez które przebiega droga krajowa nr 7 (ryc. 4) oraz miejscowości, w których aktualnie znajdują się szkoły np. Kozłów czy Dziaduszyce. W pozostałych osiedlach nastąpił ubytek ludności. Proces wyludniania się dotyczył w większym stopniu miejscowości niebędących wsiami gminnymi. Warto zwrócić uwagę, że liczba ludności w analizowanych latach zmalała aż w 125 miejscowościach (90,6\% ogółu) i dotyczyła głównie wsi małych liczących do 250 osób. Najwięcej mieszkańców, bo blisko 40\%, utraciły gminy zlokalizowane we wschodniej części powiatu: Racławice (spadek o 40,4\%), Słaboszów (spadek o 38,4\%), Książ Wielki (spadek o $38,3 \%$ ) (ryc. 3).

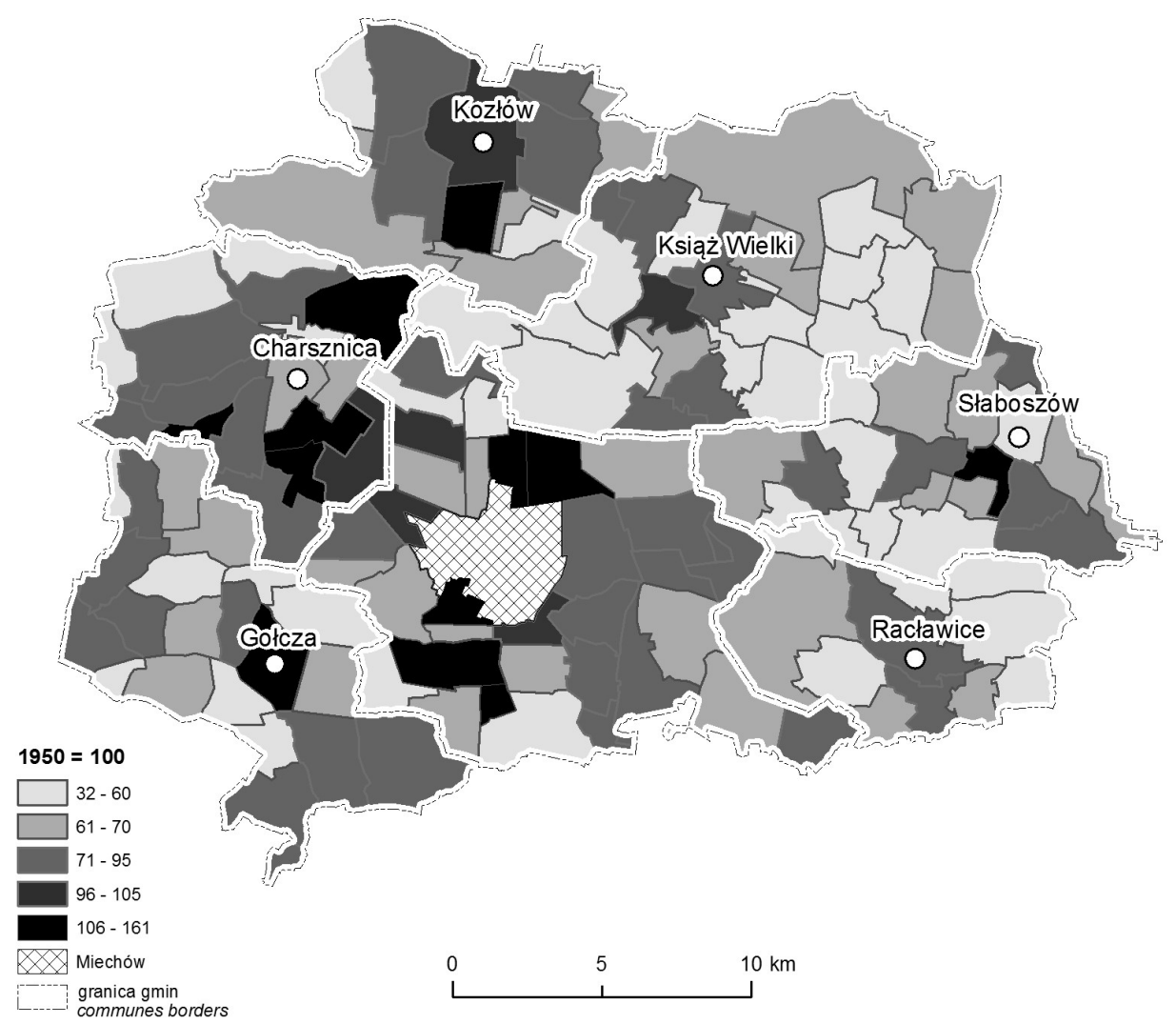

Ryc. 3. Dynamika ludności w miejscowościach powiatu miechowskiego w latach 1950-2012

Źródło: opracowanie własne na podstawie BDL GUS.

Population dynamics in the communes of Miechów district in the years 1950-2012

Source: own compilation based on Local Data Bank

Depopulacja tych obszarów jest następstwem kilku czynników. Wiąże się ona z obserwowanymi także w innych częściach kraju migracjami młodych kobiet w wieku prokreacyjnym, co negatywnie wpływa na przyrost naturalny. Emigracja obejmuje także młodych mężczyzn i inne osoby dążące do podniesienia standardu życia poprzez znalezienie lepszej 
pracy, satysfakcjonującego wynagrodzenia czy poprawę warunków mieszkaniowych. Odpływ ludności niesie za sobą nie tylko zmiany w demografii regionu, ale także pogarszanie zasobów kapitału ludzkiego, bowiem obejmuje z reguły osoby młode, lepiej wykształcone. Tym zmianom towarzyszy nasilający się proces starzenia się społeczności lokalnych. W ciągu ostatniej dekady odsetek osób w wieku poprodukcyjnym w powiecie miechowskim zwiększył się o blisko 2 punkty procentowe do poziomu bardzo wysokiego (z 19,6\% w 2003 r. do 21,3\% w 2013 r.). Jednak to, co wydaje się najważniejsze z perspektywy tego opracowania, to fakt, że uwidaczniają się trudności w realizowaniu usług społecznych. W wyniku niekorzystnych zjawisk depopulacyjnych podejmowane są decyzje o zamykaniu małych szkół wiejskich, co w konsekwencji zmniejsza młodym ludziom dostępność przestrzenną do edukacji.

\section{Dostępność szkolnictwa podstawowego w powiecie miechowskim - studium przypadku}

Poniżej przedstawiono wyniki badań dostępności do szkół podstawowych w powiecie miechowskim w 2008 oraz w 2014 r., liczonym jako czas przejazdu samochodem. Do celów badania opracowano model prędkości ruchu, wykorzystując m.in. parametry funkcjonalno-techniczne różnych kategorii dróg, bazując na modelu prędkości ruchu rozwiniętym w IGiPZ PAN (Komornicki i in. 2010). W modelu wyróżniono 8 kategorii dróg, dla których na poszczególnych odcinkach zostały obliczone średnie prędkości ruchu (na podstawie przepisów ruchu drogowego). Przypisane prędkości pomniejszono, uwzględniając występujące utrudnienia jazdy, tj. zróżnicowanie ukształtowania terenu, gęstość ludności w buforze $5 \mathrm{~km}$ w otoczeniu danego odcinka. W badaniach uwzględniono zmiany, jakie nastapiły w sieci dróg powiatu miechowskiego w latach 2008-2014. Ponadto dla pełniejszego przedstawienia dostępności czasowej do szkół, w drugiej części rozdziału wykorzystano dane dotyczące czasu, jaki zajmuje uczniom dotarcie z domu do szkoły. Dane uzyskano na postawie przeprowadzonej ankiety w publicznych szkołach podstawowych (z wyłączeniem szkół specjalnych i integracyjnych) skierowanej do wszystkich opiekunów uczniów oraz dyrektorów placówek. Próba badawcza objęła 1300 respondentów, kwestionariusze dostarczono bezpośrednio do każdej z badanych jednostek. Zwrot ankiet był na poziomie 60\%. Badania przeprowadzono w okresie od września do grudnia 2014 roku. Obecnie na obszarach wiejskich powiatu miechowskiego funkcjonuje 20 szkół podstawowych (bez integracyjnych i specjalnych) (ryc. 4).

Sieć szkół podstawowych z 2008 r. umożliwiała stosunkowo dobrą dostępność przestrzenną tych placówek z miejscowości powiatu. Czas dojazdu do najbliższej szkoły, liczony jako czas przejazdu samochodem osobowym, nie przekraczał 10 minut (ryc. 5), a jego średnia wartość wynosiła ok. 2,8 minuty. Najlepszą dostępnością szkół cechowały się gminy Kozłów i Charsznica oraz Książ Wielki, odpowiednio 1,8 i po 2,5 minuty Najdłużej dojazd do szkół zajmował w gminie Racławice (ponad 4 minuty), gdzie w miejscowości gminnej zlokalizowana była tylko jedna szkoła podstawowa. Zatem obszary o najlepszej dostępności do szkół znajdywały się w północnej i północno-zachodniej części powiatu, gdzie zagęszczenie wsi jest mniejsze, ale zamieszkuje ją większa liczba ludności.

Dostępność przestrzenna do szkół uległa znacznemu pogorszeniu w latach 2008-2014

w efekcie likwidacji wielu placówek. Średni czas dojazdu do szkoły wydłużył się na całym 


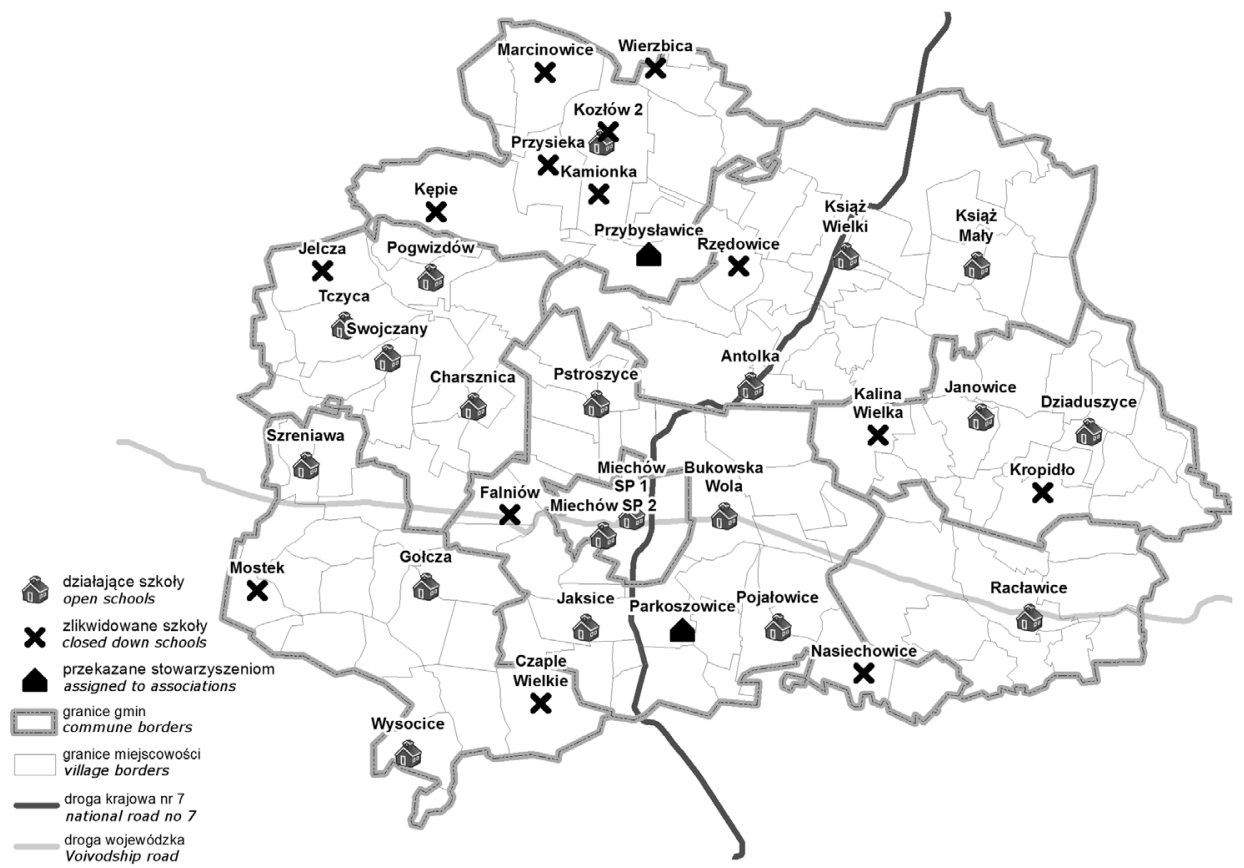

Ryc. 4. Rozmieszczenie szkół podstawowych w powiecie miechowskim w roku 2008-2014

Źródło: opracowanie własne na podstawie BDL GUS i badań własnych.

Distribution of primary schools in Miechów district in the years 2008-2014

Source: own compilation and elaboration based on Local Data Bank

omawianym obszarze o 20\%. Najbardziej wzrósł w gminie Kozłów - o 46\% (do 3,4 minuty), gdzie zlikwidowano 5 szkół podstawowych (ryc. 5). Kolejnymi gminami pod względem wzrostu czasu dojazdu do szkół są: Gołcza (28\%, do 4,1 minuty) oraz Słaboszów (22\%, do 4,1 minuty). Podawane wartości dotyczą dostępności do najbliższej placówki, natomiast rzeczywisty czas dojazdu do szkoły ujawniają badania ankietowe, które uzupełniają w istotnym stopniu wyniki przedstawionej dotąd analizy. Pokazują mianowicie, że średni czas dotarcia do szkoły od wyjścia z domu to blisko 17 minut. Należy przy tym zaznaczyć, że większość dzieci do szkoły dojeżdża autobusem szkolnym (61\% uczniów), 20\% uczniów dowożą do szkoły rodzice samochodem, a 19\% dostaje się do szkoły pieszo. Ze względu na sposób dotarcia, najdłużej zajmuje to tym uczniom, którzy dojeżdżają autobusem szkolnym, bo ponad 21 minut. Średnio blisko 14 minut zajmuje dotarcie do szkoły uczniom pieszo, natomiast średni czas dojazdu do szkoły samochodem wynosił 11 minut. Najszybciej dzieci dostają się do szkół małych, obejmujących swoim zasięgiem niewiele miejscowości (w badaniach były to szkoły w Janowicach, Parkoszowicach czy Jaksicach (poniżej 15 minut). Najdłużej natomiast zajmuje dotarcie do szkół w Gołczy, Kozłowie oraz Dziaduszycach, posiadających rozległy obszar obsługi (średnio ponad 25 minut).

Z przeprowadzonych badań wynika, że tylko w dwóch szkołach podstawowych w powiecie miechowskim dzieci do nich uczęszczające nie mają organizowanego dowozu, są to szkoły prowadzone przez stowarzyszenia. We wszystkich szkołach prowadzonych przez jednostki samorządu terytorialnego dzieci są dowożone. Powiat miechowski znaj- 
A

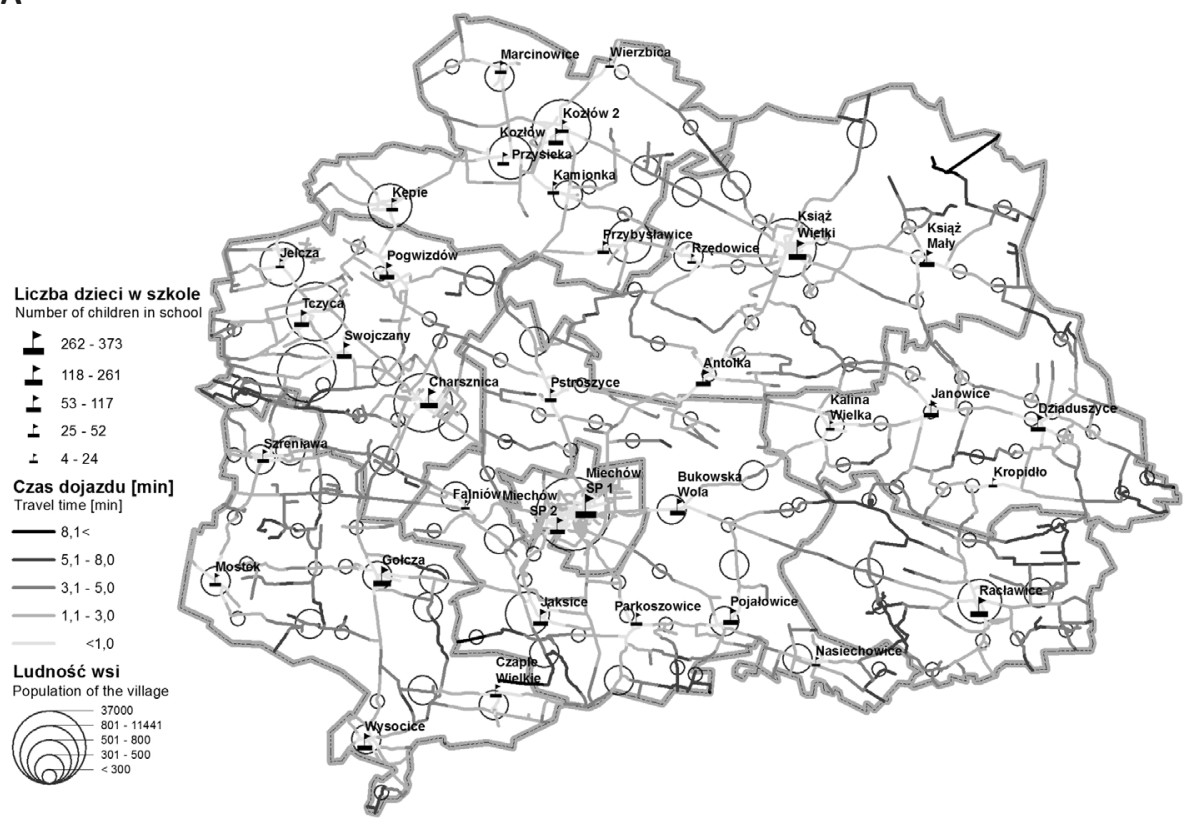

B

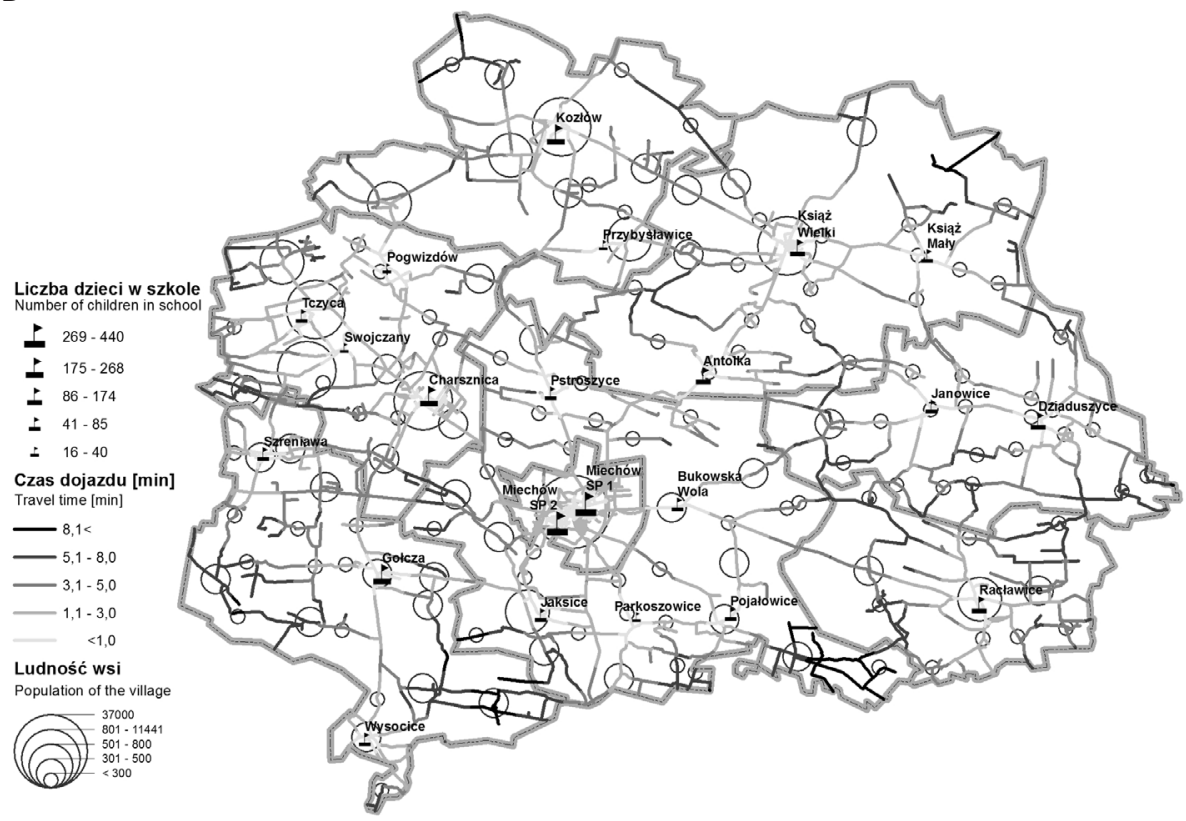

Ryc. 5. Dostępność komunikacyjna do szkół powiatu miechowskiego: A - w 2008 r., B - w 2014 r. Źródło: opracowanie własne.

Transport accessibility to schools in Miechów districts: A - 2008, B - 2014

Source: own elaboration. 
duje się na pierwszym miejscu pod względem wydatków na dowożenie dzieci do szkół podstawowych i gimnazjów z ogółu wydatków na edukację w województwie małopolskim. W 2013 r. przeznaczono 11,8\% środków na dowozy dla uczniów z ogółu wydatków na edukację (najwięcej w województwie), przy średniej dla województwa wynoszącej 3,3\%. Najwyższy odsetek wydatków na dowożenie dzieci jest w gminach o silnie rozwiniętej funkcji rolniczej, w północnej części województwa oraz w dużych gminach beskidzkich (ryc. 6). Biorąc pod uwagę liczbę zlikwidowanych szkół w powiecie miechowskim, władze samorządowe decydują się na zwiększanie kosztów dowożenia uczniów, zamiast dopłacać do nierentownych, rozproszonych placówek szkolnych.

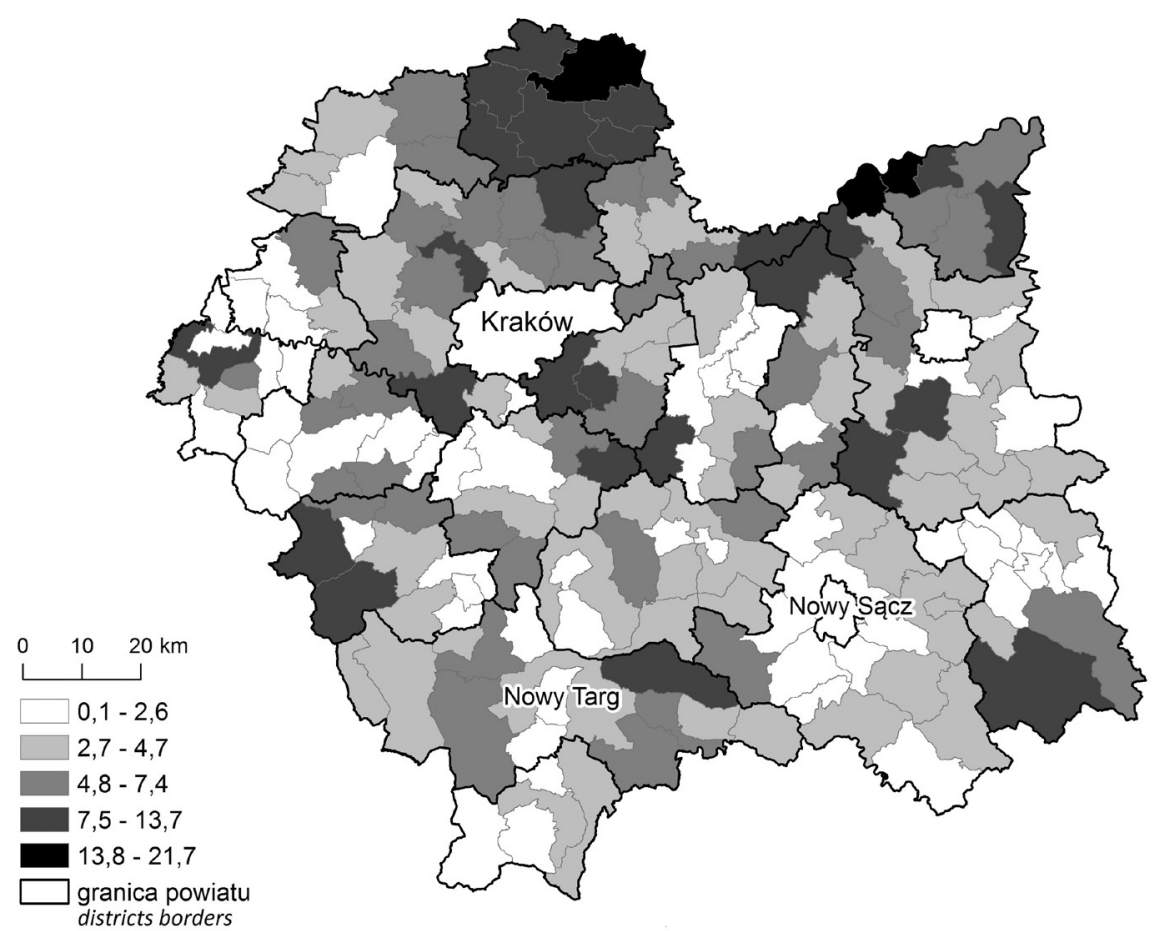

Ryc. 6. Wydatki na dowożenie dzieci do szkół w 2013 - w \% ogólnej sumy wydatków na edukację w woj. małopolskimk

Źródło: opracowanie własne na podstawie BDL GUS.

Expenditure on driving children to school in 2013 - as \% of the total expenditure on education in the Małopolskie Voivodship

Source: own compilation based on Local Data Bank

Porównując zasięgi oddziaływań szkół, mierzonych miejscem zamieszkania uczniów uczęszczających do danej szkoły, można dostrzec, że w dużej mierze pokrywają się one z obwodami szkolnymi (ryc. 7). Jak zauważył A. Bajerski (2014) według danych Ministerstwa Edukacji Narodowej ponad 25\% uczniów szkół podstawowych uczyło się w szkołach w innych obwodach. W powiecie miechowskich odsetek tego typu uczniów wynosi ok. 10\%. Z jednej strony spowodowane jest to mniejszą aktywnością w wyborze szkół rodziców zamieszkujących tereny wiejskie w stosunku do tych mieszkających w miastach (na wsi brak alternatywy). Z drugiej strony wytłumaczeniem może być też znacząco niższy 
udział rodziców z wyższym wykształceniem zamieszkujących typowo rolniczy teren powiatu miechowskiego. Jak wykazał J. Majkut (2010) jest bardzo silna zależność w wyborze szkoły (innej niż najbliższa) a udziałem rodziców z wyższym wykształceniem.

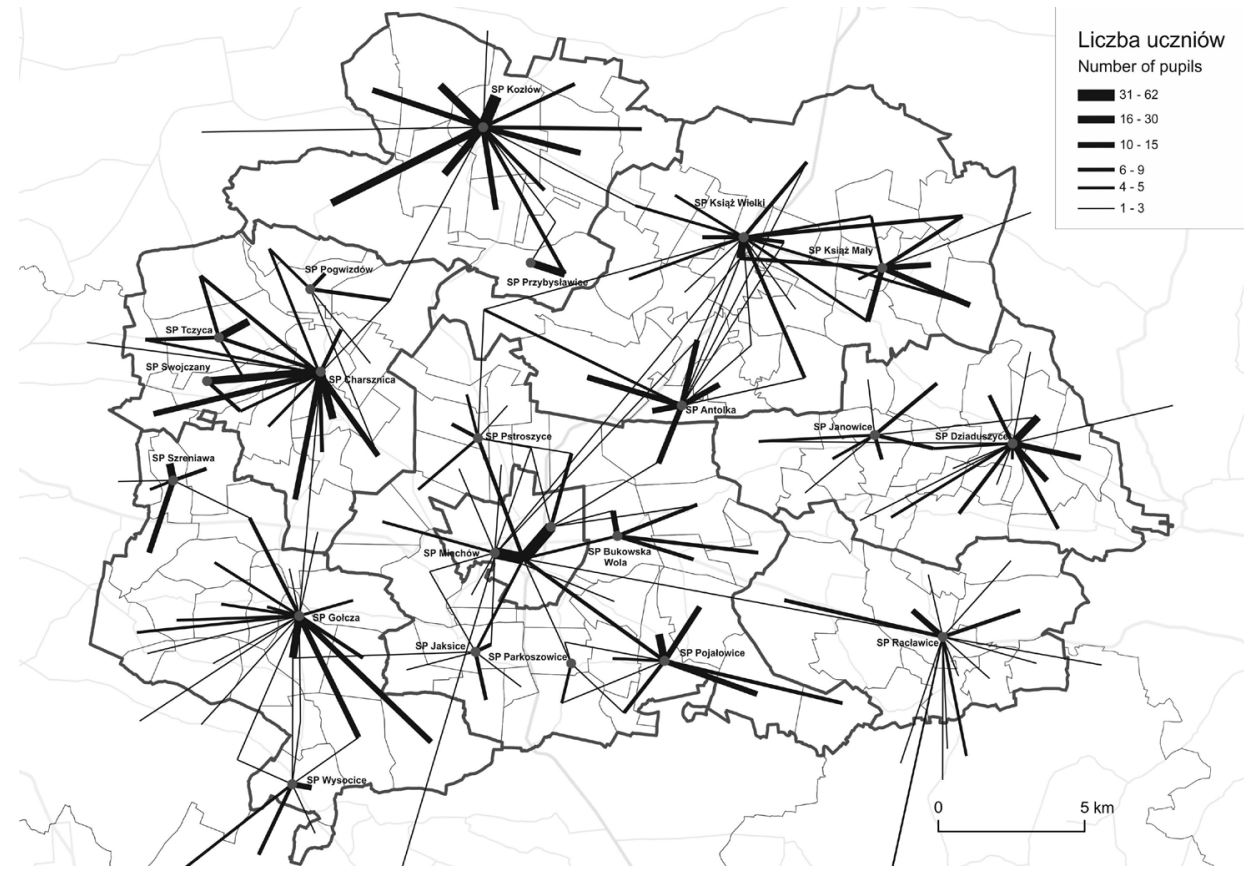

Ryc. 7. Zasięgi oddziaływań szkół podstawowych powiatu miechowskiego w 2014 roku Źródło: na podstawie badań własnych.

Impact ranges of primary schools in Miechów district in 2014

Source: own elaboration.

\section{Organizacja zajęć pozalekcyjnych w szkołach powiatu miechowskiego}

Dyrektorzy wszystkich analizowanych szkół w powiecie miechowskim organizują nieodpłatne zajęcia pozalekcyjne dla swoich uczniów. Wpływa to bardzo pozytywnie na rozwój młodych ludzi, rozwijając ich zainteresowania, co jest szczególnie ważne, gdy rodziców nie stać na opłacanie dodatkowych zajęć pozalekcyjnych. Można wymienić następujące nieodpłatne zajęcia pozalekcyjne organizowane przez szkoły: zajęcia wyrównawcze, kółka przedmiotowe dla zdolnych uczniów, językowe oraz zajęcia sportowe, artystyczne (plastyczne, wokalne, taneczne). Co ważne, większość zajęć dodatkowych, na które uczęszczają uczniowie z badanych szkół, znajduje się w miejscowości, do której uczęszczają do szkoły. Jeżeli natomiast dzieci uczęszczają na zajęcia pozalekcyjne poza miejscowością szkolną, to korzystają z oferty miasta powiatowego - Miechowa. Jedynie ta miejscowość w powiecie dysponuje krytą pływalnią, szkołą piłkarską, co pozwala jeszcze w większym stopniu rozwijać zainteresowania uczniów. Głównym powodem braku uczestnictwa w zajęciach pozalekcyjnych wskazywanym przez opiekunów były problemy z dojazdem (25\% respondentów) oraz brak organizowanych zajęć przez szkołę. Wska- 
zania braku organizowanych zajęć przez szkołę mogą wynikać z niezrozumienia pytania przez respondentów (część badanych traktowała zajęcia wynikające z Karty Pracy Nauczyciela, jako obowiązkowe, a nie pozalekcyjne), bowiem z badań przeprowadzonych z dyrektorami placówek wynika, że w każdej z analizowanych szkół takie zajęcia są organizowane.

Ważnym elementem z punktu widzenia organizacji zajęć pozalekcyjnych jest liczba dowożonych uczniów oraz godzina odjazdu autobusów, z których korzystają. Z przeprowadzonych badań wynika, że nie ma większego znaczenia, czy dziecko mieszka blisko szkoły, czy też dojeżdża do szkoły z większej odległości. Co ciekawe, istnieją szkoły, w których większość uczniów uczęszczających na zajęcia pozalekcyjne to osoby dojeżdżające (Tczyca, Bukowska Wola, Racławice). Wiąże się to z tym, że jeśli dziecko mieszka blisko i do szkoły dociera pieszo, to nie zostaje na dodatkowe zajęcia, a w przypadku gdy zajęcia organizowane są później (po lekcjach), to na nie już nie wraca. W przypadku, gdy do szkoły większość dzieci jest dowożona (np. Książ Mały), to transport jest tak dostosowany, aby dzieci mogły swobodnie uczestniczyć także w zajęciach dodatkowych.

\section{Podsumowanie}

Jak wynika z przedstawionej analizy, w ostatnich latach bardzo dynamicznie zmienił się krajobraz edukacyjny wsi. Widoczne jest to zwłaszcza w rejonach depopulacyjnych, które tradycyjnie pełnią funkcje rolnicze. Jednocześnie należy zaznaczyć, że zapoczątkowany w latach 90. proces decentralizacji oświaty na poziomie podstawowym, wkroczył w nowy etap. Po przekazaniu szkół jednostkom samorządu terytorialnego można obecnie obserwować proces przekazywania odpowiedzialności za kształt edukacji na tym szczeblu stowarzyszeniom i organizacjom społecznym. Przy założeniu, że liczba dzieci, przy których gminy są w stanie utrzymać wiejską szkołę nie powinna być mniejsza niż 70 uczniów, w województwie małopolskim w dalszym ciągu zagrożonych likwidacją jest 275 szkół. Część spośród tych szkół jest już prowadzona przez stowarzyszenia czy organizacje społeczne, jednak i w ich przypadku, może okazać się, że pomimo mniejszych kosztów funkcjonowania (brak obowiązku stosowania regulacji wynikających z Karty Nauczyciela) ciągle utrzymujące się negatywne procesy demograficzne doprowadzą do ich zamknięcia. Niezmiennym problemem wydaje się dylemat, czy utrzymywać sieć małych wiejskich szkół, które są kosztowniejsze i często edukacja w nich odbywa się w gorszych warunkach, ale są blisko domu ucznia. Czy też tak przeorganizować sieć szkół, aby edukacja odbywała się w dużych szkołach, często lepiej wyposażonych, ale oddalonych od rodzinnego domu. W okresie, kiedy szukanie oszczędności staje się priorytetem dla władz lokalnych, zwycięża w ostatnich latach to drugie podejście. Jak zauważa większość badaczy (Szyszko-Bohusz 1974; Kwieciński 1975; Piwowarski 1992; Guzik 2003) czasochłonne dojazdy do szkoły są dość dużym obciążaniem dla uczniów i mogą negatywnie wpływać na wyniki szkolne. Jednak jak wynika z badań R. Guzika (2013), który analizował kariery szkolne wiejskiej młodzieży, znacznie lepsze wyniki egzaminów uzyskiwali uczniowie dojeżdżający ze średnich i dużych odległości (badania dotyczyły zdawalności egzaminów zawodowych). Zatem pokonywanie dłuższej drogi do szkoły nie musi negatywnie odbijać się na wynikach szkolnych, a niekiedy może nawet stymulować lepszy wynik. Dotyczy to zwłaszcza sytuacji, kiedy coraz więcej rodziców decyduję się na świa- 
domy wybór szkoły zlokalizowanej w dalszej odległości, poza obwodem szkolnym (zob. Bajerski 2014; Majkut 2010). Świadczy to o rosnącej determinacji rodziców w zapewnieniu podopiecznym jak najlepszych warunków do nauki. Nierozstrzygniętą jest jednak kwestia wpływu likwidowanych szkół na sposób identyfikacji zarówno dzieci i rodziców oraz pozostałych mieszkańców wsi z miejscem, które dotyka narastająca marginalizacja. Zatem ta niezwykle ciekawa problematyka wymaga dalszych pogłębionych badań dla identyfikacji procesów społecznych zachodzących na polskiej wsi pod wpływem reorganizacji sieci szkół.

\section{Literatura}

Bajerski A., 2011, Organizacja przestrzenna i funkcjonowanie usług edukacyjnych w aglomeracji poznańskiej, Bogucki Wydawnictwo Naukowe, Poznań.

Bajerski A., 2012, Przemieszczenia uczniów między obwodami szkolnymi a zróżnicowanie wyników publicznych szkół podstawowych i gimnazjów. Przypadek Poznania, Studia Regionalne i Lokalne, 2, s. 62-76.

Bajerski A., 2014, Lokalne konflikty wokót rejonizacji kształcenia na obszarach wiejskich w Polsce, Studia Regionalne i Lokalne, 4, s. 125-143.

Czapiewski K., Janc K., 2011, Accessibility to education and its impact on regional development in Poland, [w:] N. Adams, G. Cotella, R. Nunes (red.), Territorial Development, Cohesion and Spatial Planning - knowledge and policy development in an enlarged EU, Routledge, London, New York, s. 345-372.

Czapiewski K., Janc K., 2012, Dostępność do edukacji, jakość kształcenia i poziom wykształcenia mieszkańców a struktura funkcjonalna gmin województwa mazowieckiego, Mazowsze Studia Regionalne, 10, s. 33-51.

Dej M., Guzik R., 2011, The rural challenge: Spatial accessibility to secondary education in Poland within the transformation period, [w:] Á. Erőss, D. Karácsonyi, (red.) Geography in Visegrad and neighbour countries: Regional socio-economic processes in Central and Eastern Europe - 20 years in transition and 2 years in global economic crisis, Geographical Research Institute, Hungarian Academy of Sciences, Budapest, 65-74.

Dolata R., 2008, Szkoła - segregacje - nierówności, Wydawnictwa Uniwersytetu Warszawskiego, Warszawa.

Domalewski J., 2010, Edukacja a procesy rozwoju obszarów wiejskich, [w:] M. Stanny, M. Drygas (red.), Przestrzenne, społeczno-ekonomiczne zróżnicowanie obszarów wiejskich w Polsce. Problemy i perspektywy rozwoju, Instytut Rozwoju Wsi i Rolnictwa PAN, Warszawa.

Domalewski J., 2002, Zróżnicowanie oświaty na obszarach wiejskich, [w:] D. Waloszek, K. Wąż (red.), Nadzieja na zmianę. Szanse edukacyjne młodego pokolenia ze środowiska wiejskiego, Ośrodek Doskonalenia Nauczycieli, Zielona Góra.

Flaga M., Wesołowska M., 2002, Warunki kształcenia dzieci i młodzieży na obszarach wiejskich w województwie lubelskim, Studia Obszarów Wiejskich, 2, s. 83-93.

Guzik R., 2003, Przestrzenna dostępność szkolnictwa ponadpodstawowego, Instytut Geografii i Gospodarki Przestrzennej UJ, Kraków.

Guzik R., 2013, Edukacja i dojazdy do szkoły, [w:] R. Guzik, K. Wiedermann (red.), Zawodowy start. Przestrzenne uwarunkowania karier szkolnych i dalszych losów absolwentów, Wojewódzki Urząd Pracy w Krakowie, Kraków, s. 17-46. 
Guzik R., Wiedermann K. (red.), 2013, Zawodowy start. Przestrzenne uwarunkowania karier szkolnych i dalszych losów absolwentów, Wojewódzki Urząd Pracy w Krakowie, Kraków.

Jędrzejczyk D., 2001, Podstawy geografii ludności, Wydawnictwo Akademickie DIALOG, Warszawa.

Komornicki T, Śleszyński P., Rosik P., Pomianowski W., 2010, Dostępność przestrzenna jako przesłanka kształtowania polskiej polityki transportowej, Biuletyn KPZK PAN, 241, Warszawa.

Kozakiewicz M., 1975, Zróżnicowanie dostępu młodzieży do kształcenia w 1970 r., IRWiR PAN, Warszawa.

Kwieciński Z., 1975, Środowisko a wyniki pracy szkoły, IRWiR PAN, Warszawa.

Majkut J., 2010, Powody wyboru szkoły gimnazjalnej w wypowiedziach rodziców, XVI Konferencja Diagnostyki Edukacyjnej, Toruń 2010.

Moseley M. J., 1979, Accessibility: The Rural Chalenge, Methuen, London.

Ozga W., 1960, Organizacja szkolnictwa w Polsce, Państwowe Zakłady Wydawnictw Szkolnych, Warszawa.

Ozga W., 1974, Rozmieszczenie szkół w Polsce, Wydawnictwa Szkolne i Pedagogiczne, Warszawa.

Pilch T., 2002, Równość szans edukacyjnych w kontekście warunków społecznych i regulacji reformy oświaty, [w:] D. Waloszek, K. Wąż (red.), Nadzieja na zmianę. Szanse edukacyjne młodego pokolenia ze środowiska wiejskiego, Ośrodek Doskonalenia Nauczycieli, Zielona Góra.

Piwowarski R., 1992, Sieć szkolna a dostępność kształcenia, PWN, Warszawa.

Piwowarski R., 2000, Szkoły na wsi-edukacyjne wyzwanie, Instytut Badań Edukacyjnych, Warszawa.

Szyszko-Bohusz A., 1974, Dojazdy młodzieży do szkół, Nauka dla Wszystkich, 225, PWN, Warszawa-Kraków.

Uliszak R., 2013, Wizja wsi małopolskiej - rok 2050 - spodziewane scenariusze zmian, Studia Obszarów Wiejskich, 31, s. 67-82.

Wilkin J. (red.), 2003, Podstawy strategii zintegrowanego rozwoju rolnictwa i obszarów wiejskich w Polsce, Wyd. Uniwersytetu Warszawskiego, Warszawa.

Taylor Z., 1999, Przestrzenna dostępność miejsc zatrudnienia, kształcenia i usług a codzienna ruchliwość ludności wiejskiej, Prace Geograficzne IGiPZ PAN, 171, Warszawa.

\section{Summary}

The subject of this work concerns primary education in rural areas of the Małopolskie Voivodship. The research is particularly focused upon Miechów district, which is located in the south-western part of the Małopolskie Voivodship. The authors strived to present the impact of demographic conditions upon the network of schools in this strongly depopulating region and identify to what extend trends among population limit the accessibility to after-school activities for children and adolescents. The aim of this paper is to present the location and accessibility of primary education institutions in Miechów district and also to assess the organization of after-school activities which is a major factor in ensuring equal opportunities of education among children and adolescents.

As a result of unfavorable demographic tendencies, schools are being closed down. In the Małopolskie Voivodship 143 (12.3\%) primary schools were liquidated over the years 2000-2012 and these include mainly small, rural schools in agricultural areas. The number of pupils attending primary schools decreased even more. Between the years 2000-2012 the number fell by over 80 thousand (from 280 thousand to just under 200 thousand which constitutes 30\%). 
The authors attempted to determine essential information about children's travel to schools such as: residence place of children that are brought to particular schools, the average time of reaching school from where they live and the means of transport that a child chooses to reach the school. In 2008 the location of primary schools in the area of Miechów district allowed for relatively good accessibility within its borders. However, during the years 2008-2014 the spatial accessibility greatly decreased as a result of many institutions being closed down. The average time a child needs to reach school extended by $20 \%$ in the whole discussed area. The highest increase was observed in Kozłów commune, in which the time extended by $46 \%$ (to 3,4 minutes) and where 5 primary schools were liquidated. 